${ }^{1}$ Запорізький державний медичний університет,

${ }^{2}$ КВНЗ “Запорізький медичний коледж” ЗОР

\title{
ВМОТИВОВАНІСТЬ ЯК ЧИННИК ФОРМУВАННЯ ПРОФЕСІЙНОЇ СПРЯМОВАНОСТІ У СТУДЕНТІВ МЕДИЧНОГО ВНЗ
}

\section{O. A. Rastvorov ${ }^{1}$ I. O. Rastvorov ${ }^{2}$ \\ MOTIVATION AS A FACTOR OF CAREER CHOICE FORMING FOR THE STUDENTS OF HIGHER MEDICAL SCHOOL}

\author{
${ }^{1}$ Zaporizhzhia State Medical University, \\ 'Zaporizhzhia Medical College
}

\begin{abstract}
Мета роботи - визначення існуючого ступеня мотивації та ії компонент (досягнення, професійної орієнтації та афіляції), їх розвитку в процесі навчання студентів медичного ВНЗ I-II рівня акредитації.

Основна частина. Було проведено анкетування серед 95 студентів медичного ВН3 на різних етапах навчання з урахуванням наявності досвіду роботи. За результатами оцінювання, було визначено низький, середній та високий рівні сформованості мотивації. При вступі до ВН3 вмотивовані на отримання саме медичної спеціальності 50-60 \% абітурієнтів, які не мають попереднього досвіду роботи. Проте майже всі студенти, що мали досвід практичної роботи, були вмотивовані на отримання саме медичної спеціальності. У процесі навчання відбувається розвиток як мотиваційної компоненти в цілому, так і її складових. За період навчання рівень мотивації у студентів зростає в 1,35-1,6 раза, і має залежність від наявності професійного досвіду. Мотивація до медичної діяльності на середньому та високому рівнях на період завершення ВНЗ сформована у 75 \% студентів із обмеженим фаховим досвідом і в $90 \%$ - за умови його наявності.

Висновок. При відборі абітурієнтів до вступу до медичного ВНЗ необхідно враховувати не лише наявний рівень їх знань за загальноосвітніми предметами, але враховувати їх мотивацію до отримання медичної освіти.
\end{abstract}

Ключові слова: вмотивованість; професійна спрямованість; студенти; медичний ВНЗ.

The aim of the work - to determine the current level of motivation and its components (achievement, professional focus and affiliation), their development in the study process of students of medical university of the I-II accreditation level.

The main body. The survey was conducted among 95 students of medical university on different stages of study and their work experience was taken into account. According to the results of evaluation low, middle and high level of motivation forming were determined. During the admission to the university 50-60 \% of enrollees, who don't have practical experience, are motivated to get medical specialty. In spite of this fact, almost all of the students who have practical experience were motivated exactly for getting medical specialty. During the studies the development of motivation component in general and its components in particular were made. During the study process the level of motivation among the students increases in 1.35-1.6 times and it has a correlation with existence of practical experience. The high level of motivation for medical practice is formed among $75 \%$ of students with limited previous professional experience and among $90 \%$ students having it.

Conclusion. During the selection process of students entering medical university it is necessary to consider not only the current level of their knowledge of general disciplines, but also to take into account their motivation for medical education.

Key words: motivation; career choice; students; medical school.

Вступ. Сучасні вимоги ринкової економіки та інформаційно-технологічного розвитку потребують формування мобільної та конкурентоспроможної особистості. Адекватне сприйняття та реагування на нові фактори, оперативність і самостійність у прийнятті рішень, соціальна відповідальність визначають здатність особистості до соціальної та професійної мобільності, що набуває все більшого

(C) О. А. Растворов, І. О. Растворов значення у всіх сферах діяльності. Знання перетворюються в один із провідних факторів економічного розвитку. Система професійної освіти, як соціальний інститут, набуває провідної ролі у побудові економіки, основаної на знаннях [1].

Вмотивованість має суттєвий вплив на отримання певної професійної освіти та подальшої роботи за отриманим фахом [2, 3]. В Україні найбільша, порівняно з іншими галузями економіки, відповід- 
ність працевлаштування за отриманою спеціальністю відзначається в медицині - 94,5 \% [4].

Мотиваційний компонент поєднує цілі, мотиви й потреби в професійному навчанні та вдосконаленні, особистісному саморозвитку, ціннісні установи професійної діяльності, стимулює творчість, передбачає інтерес до професії. Мотивація - це потреба особистості в загальних і професійних знаннях, оволодінні ефективними засобами організації та реалізації своєї діяльності, в ефективній взаємодії з іншими особами [2, 5-7].

Мотиваційний компонент поєднує мотиви досягнення, професійної орієнтації та афіляції [5-7]. Мотив досягнення якісних результатів праці для подальшої реалізації особистісних потреб є основою активності в процесі спільної професійної діяльності. Мотив профорієнтації спрямований на вибір професії, розвиток специфічних знань і вмінь особистості, розширення її професійних можливостей. Суттєвим мотивом спільної професійної діяльності $є$ мотив афіляції, що проявляється у взаємодії й довірі, підтримці партнерів по спілкуванню, визнанні їх особистісних якостей і досягнень.

Мета роботи - встановити рівень сформованості і розвиток мотиваційного компонента професійної мобільності та його складових у процесі особистісно-орієнтованого навчання в медичному ВНЗ I-II рівнів акредитації.

Основна частина. Визначення сформованості і розвитку мотиваційного компонента та його складових було проведено серед студентів КВНЗ “Запорізький медичний коледж” 3OP I-II рівня акредитації.

Серед студентів були сформовані три групи залежно від терміну і форми (денне, вечірнє) навчання: 1-ша група (33 студенти) на початку навчання у ВНЗ за денною формою, 2-га (32 студенти) і 3-тя (30 студентів) наприкінці навчання за денною і вечірньою формами відповідно.

До вступу до ВНЗ студенти в групах відрізнялися за досвідом роботи. У 1-й і 2-й групах не працювали до вступу до коледжу 4/5 і 3/4 відповідно, а серед тих, що раніше працювали, досвід роботи в медицині в обох групах мали менш ніж 1/10. Серед студентів з вечірньою формою навчання досвід роботи мали всі, з них до вступу до коледжу в медичних установах працювала майже половина. У процесі подальшого навчання відзначались зміни в трудовій зайнятості студентів: у першій групі працювало 18 \% осіб, з них у медицині - 2/3, у другій - 28 \%, з яких у галузі майбутньої професії-
3/4, у третій групі працювати продовжували всі, а в галузі охорони здоров’я - майже 90 \%.

Оцінку мотиваційного компонента та його складових проводили за методом анкетування. Було розроблено анкету, що включала питання, які стосувалися мотивів вибору професії, досягнення кращих результатів і афіляції. Дана анкета дозволяла оцінити профорієнтацію студентів та їх задоволеність своєю спеціальністю, спрямованість на підвищення своїх результатів, схильність до партнерства і взаємодії. Кожній відповіді при оцінюванні присвоювався бал, за сумою яких визначався індивідуальний рівень мотиваційного компонента студента та групи студентів у цілому. За результатами загального оцінювання мотиваційного компонента та його складових, виділяли низький, середній і високий рівні розвитку мотивації.

При вступі до ВНЗ трохи більше половини (55 \%) студентів 1-ї групи мали сформовані причини до отримання медичної професії та лише 2/5 (42%) мали уявлення про особливості професії на основі особистісного досвіду, спостереження чи сімейної традиції. Одночасно більш ніж 1/4 студентів не були спрямовані до отримання саме медичної освіти (27 \%) і мали обмежені знання про професійну діяльність у медицині (28 \%). Подібна ситуація мала місце і в студентів 2-ї групи - у 3/5 (61 \%) студентів були сформовані причини до отримання професії і половина (50 \%) була обізнана в особливостях професійної діяльності. Серед цієї групи під час вступу до коледжу 1/4 не мала сформованого усвідомлення про майбутню професійну діяльність (24\%) і мала обмежені знання про неї (25 \%). Значно відрізнялись у цьому плані студенти 3-ї групи, їх вибір був більш свідомий і обгрунтований - майже всі (96 \%) мали сформовані причини отримання медичної освіти і були обізнані (86 \%) в майбутній професійній діяльності.

Оцінка привабливості медичної спеціальності змінювалась відповідно до терміну навчання і наявності особистісного досвіду. Студенти 1-ї групи майже однаково відзначали як фактор привабливості саме процес медичної діяльності, її високу відповідальність і соціальну значимість (39 \%), так і можливість отримання “більших” непрямих соціальних преференцій (40 \%), інші, як фактор привабливості, визначали потребу у фахівцях даної професії і можливість знайти роботу. В 2-й групі вже достатньо сформоване уявлення про особливості медичної діяльності, бажання займатися медициною обгрунтовували саме процесом професійної 
діяльності та її соціальною значимістю 50 \%, постійною потребою у фахівцях - $35 \%$, отриманням соціальних преференцій - 15 \%. Студенти 3-ї групи мали не лише уявлення про особливості роботи у медичній галузі, а й більшу відповідальність основними чинниками подальшої професійної роботи вони визначали саме процес медичної діяльності, її значимість (65 \%) або можливість знайти роботу і постійну потребу у спеціалістах (31 \%).

Спостерігались суттєві відмінності між різними групами у відношенні до отримання і засвоєння навчального матеріалу, факторів, які впливають на якість навчання, та спрямованості на подальше кар'єрне зростання.

Вивчення більшості навчальних дисциплін чи, як мінімум, спеціальних вважали за необхідне 28 \% студентів 1-ї групи, 56 \% - в 2-й групі й 86 \% студентів 3-ї групи, віддавали перевагу оволодінню практичними навичками і вміннями чи сподівалися навчитися в процесі подальшої практичної роботи 57 \%, 34 \% і 10 \% відповідно, інші студенти не вважали за необхідне наявність знань та вмінь для подальшого працевлаштування. На початку навчання у студентів ще не сформувалось достатнє розуміння необхідності комплексності знань, існує уявлення, що можливо відкласти навчання чи отримати лише практичні навички, та, навіть, про другорядність знань. На етапі закінчення навчання студенти, які мають недостатній практичний досвід, вже розуміють необхідність отримання як теоретичних, так і практичних знань, проте у частини з них ще зберігається думка про відсутність необхідності отримання знань у коледжі. Проте студенти, що закінчують навчання і мають досвід практичної роботи, визнають необхідність наявності знань і вмінь, у більшості випадків вважають, що їм у подальшому знадобиться більшість отриманої інформації.

Серед чинників, що впливають на якість навчання, наявність знань, як підгрунтя для подальшої професійної діяльності, визначали 25 \% у 1-й групі студентів, $41 \%$ - у 2-й та 76 \% - у 3-й, обгрунтовували особистісними мотивами, відповідно, $63 \%$, 53 \% і 24 \%, лише в 1-й та 2-й групах були студенти, які не були зацікавлені в результатах навчання. Розуміння отримання якісних знань зростає залежно від терміну навчання і особливо суттєво збільшується у студентів з досвідом практичної роботи. Амбіційні мотиви якісного навчання помірно присутні у всіх групах студентів. Значний вплив на якість навчання студентів денної форми має матері- альна стимуляція і батьківський контроль. Байдужа до результатів навчання лише незначна кількість студентів денної форми.

По-різному студенти сприймали і своє майбутнє кар'єрне зростання. Подальше навчання в межах своєї кваліфікації чи в медичному університеті планували в 1-й групі 42 \% студентів, у 2-й групі - 59 \%, а у 3-й - 73 \%. При наявності можливості чи необхідності додаткове навчання згодні отримувати 43 \%, 35 \% і 24 \% відповідно. Спрямованість на подальшу професійну освіту та її необхідність зростала відповідно до термінів навчання. Особливо необхідність подальшої професійної освіти відзначають студенти, які вже мають практичний досвід і працюють у галузі охорони здоров'я.

У процесі навчання змінюється й рівень підтримки та взаємодії з партнерами (мотив афіляції). У процесі роботи повністю чи частково підтримають партнера, нададуть йому допомогу і визнають його досягнення 60 \% студентів 1-ї групи, 75 \% в 2-й і та 93 \% - у 3-й групі, лише частково підтримають 18 \%, 16 \% і 7 \% відповідно. Оскільки після вступу до ВНЗ студенти ще сприймають себе як конкуренти, а їх колектив не сформовано, то 22 \% студентів вважає за можливе залишити партнера напризволяще, або не визнавати його досягнень, у подальшому, в процесі навчання і формування колективу, частка таких студентів скорочується до 9 \% в 2-й групі, а серед студентів 3-ї групи не визначалась. Зі збільшенням терміну навчання, набуття практичного досвіду роботи в медицині відзначається прогресивне зростання мотиву афіляції у їх взаємодії та відношеннях.

Було проведено індивідуальний, а на його основі інтегральний аналіз рівня сформованості вмотивованості у студентів КВНЗ “Запорізький медичний коледж” ЗОР за результатами анкетування, що наведено на рисунку 1.

У студентів у процесі навчання спостерігається загальна тенденція до зменшення низького рівня сформованості мотиваційного компонента, деякого прогресивного зростання середнього рівня та суттєвого збільшення високого рівня вмотивованості залежно від терміну навчання, набуття чи наявності досвіду практичної роботи в медицині.

Найбільш часто, незалежно від терміну і форми навчання, у студентів відзначався середній рівень вмотивованості - у 49 \% при вступі до медичного BH3, на етапі завершення навчання у студентів з обмеженим практичним досвідом роботи він зростав до 56 \%, а у студентів з наявністю досвіду роботи - 


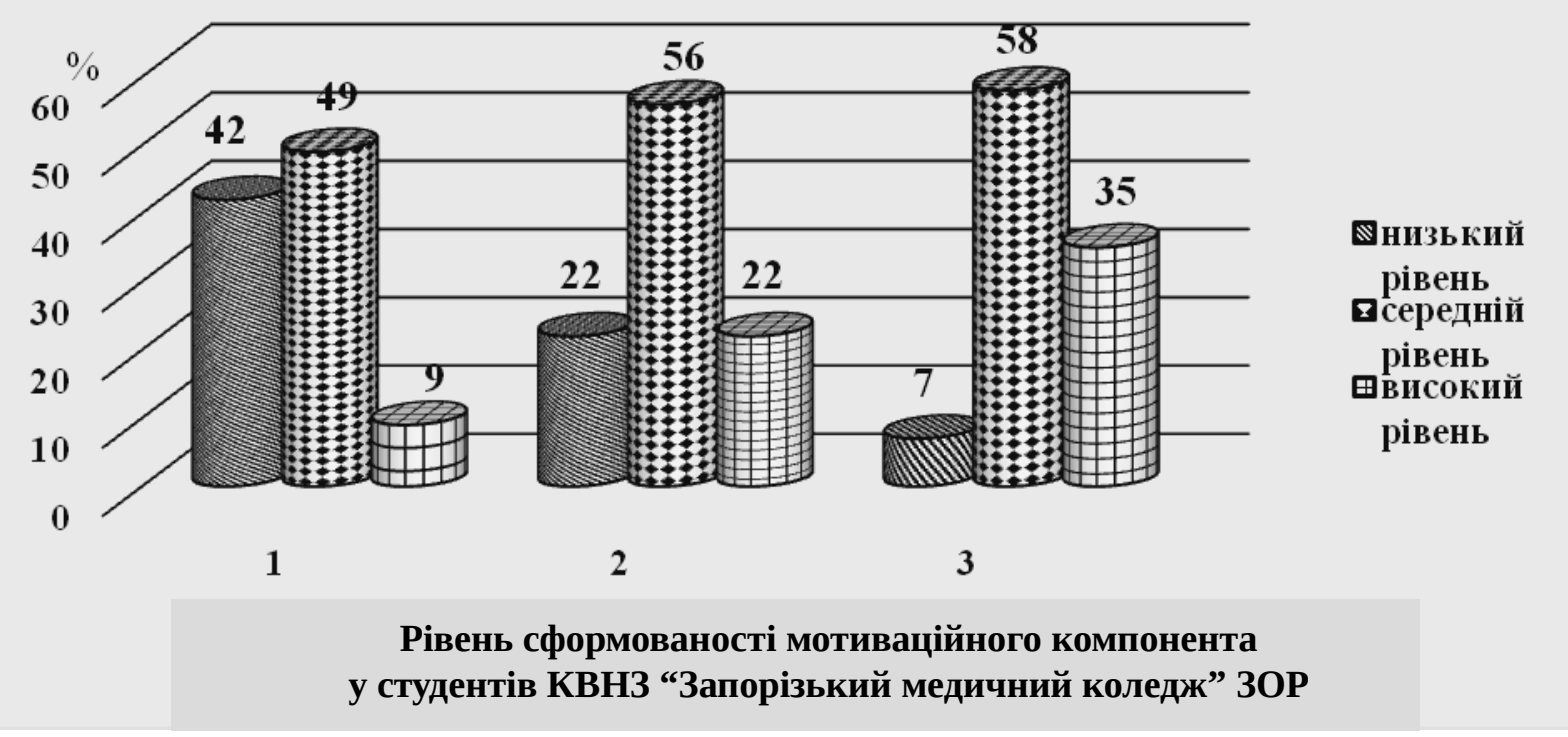

Рис. 1. Розподіл студентів КВНЗ “Запорізький медичний коледж” ЗОР різних груп за інтегральним рівнем розвитку мотиваційного компонента в процесі навчання.

до 58 \%. Значно суттєвими були зміни в динаміці низького і високого рівнів. Низька вмотивованість найбільш часто (42 \%) спостерігалась при вступі до коледжу, в подальшому її частота скорочувалась і становила на час завершення навчання 22 \% і 7 \% відповідно у студентів з недостатнім практичним досвідом чи з його наявністю. Протилежна тенденція відзначалась у рівні високої вмотивованості на початку навчання iï мали лише 9 \% студентів, а при закінченні - 22 \% студентів денної форми і $35 \%$ студентів вечірньої форми навчання.

Висновки. Рівень мотиваційного компонента і його складових у студентів медичного коледжу зростає в процесі навчання і його сформованість збільшується у 1,35 раза, а при наявності фахового досвіду - у 1,6 раза. На вибір професії, в першу чергу, впливають особистий досвід і сімейна традиція. На початковому етапі освіти професійно орієнтовані на отримання медичної професії 3/4 студентів без загального досвіду роботи і майже всі з трудовим досвідом. Необхідність отримання знань усвідомлюють 3/5 студентів на початку навчання, а наприкінці - 4/5 з недостатнім досвідом роботи і практично всі, які його мають. Необхідність подальшого професійного вдосконалення вважають за потребу 2/5 студентів, які розпочали навчання та, залежно від відсутності чи наявності професійного досвіду, 3/5 і 3/4 відповідно. У процесі навчання зростає розуміння необхідності взаємодії, взаємодовіри і підтримки в професійній діяльності. Наприкінці навчання мотиваційний компонент на середньому і високому рівнях сформовано у 3/4 студентів 3 обмеженим фаховим досвідом і у 9/10 - при його наявності. Медицина є специфічною професійною діяльністю, тому відбір вмотивованих на її виконання студентів та розвиток у процесі навчання їх спрямованості на якісну реалізацію своїх професійних якостей мають суттєве значення в процесі професійної підготовки фахівців медичної галузі.

3. Цехмістер Я. В. Відбір учнів на професії медичного профілю: аналіз зарубіжного досвіду / Я. В. Цехмістер // Неперервна професійна освіта: теорія і практика. - 2001. Вип. 2. - С. 163-171.

4. Огай М. Освітні траєкторії населення та їх вплив на професійну мобільність / М. Огай, М. Романчук // Україна: аспекти праці. - 2014. - № 5. - С. 20-27.

5. Тарасова И. В. Мотивация сестринского персонала / И. В. Тарасова // Сестринское дело. - 2009. № 2. - C. 13-15. 
6. Тихолаз С. І. Педагогічні умови розвитку професійної спрямованості студентів вищих медичних навчальних закладів : автореф. дис. канд. пед. наук / С. І. Тихолаз. - Вінниця, 2011. - 20 с.

\section{References}

1. Kremen, V.H. (Ed.), Andrushchenko, V.P., Ziaziun, I.A., Kremen, V.H., Maksymenko, S.D., Nychkalo, N.H., Sysoieva, S.O., Tsekhmister, Ya.V., \& Chalyi, O.V. (2003). Neperervna profesiina osvita: filosofiia, pedahohichni paradyhmy, prohnoz: monohrafiia [Continuous professional education: philosophy, pedagogical paradigms, prediction: monograph]. Kyiv: Naukova dumka [in Ukrainian].

2. Nelovkina-Bernal, O.A. (2010). Formuvannia profesiinoi spriamovanosti studentiv medychnykh spetsialnostei na pochatkovomu etapi navchannia [Formation of professional orientation of students of medical specialties at the initial stage of training]. Candidate's Extended abstract. Luhansk [in Ukrainian].

3. Tsekhmister, Ya.V. (2001). Vidbir uchniv na profesii medychnoho profiliu: analiz zarubizhnoho dosvidu [Selection of students in the medical profession: analysis of foreign experience]. Neperervna profesiina osvita: teoriia $i$ praktyka - Continuing Professional Education: Theory and Practice, 2, 163-171.

4. Ohai, M., \& Romanchuk, M. (2014). Osvitni traiektorii naselennia ta yikh vplyv na profesiinu mobilnist [Edu-
7. Хабусєва М. С. Становлення мотиваційної сфери майбутніх медичних працівників: психолого-педагогічні передумови / М. С. Хабусєва // Вісник Національної академії Державної прикордонної служби України. - 2013. Вип. 3 [Електронний ресурс]. - Режим доступу : http:// nbuv.gov.ua/UJRN/Vnadps_2013_3_39-Назва з екрана.

cational trajectories of the population and their impact on professional mobility]. Ukraina: aspekty pratsi - Ukraine: Aspects of Work, 5, 20-27 [in Ukrainian].

5. Tarasova, I.V. (2009). Motivatsiya sestrinskogo personala [Motivation of nursing staff]. Sestrinskoye delo - Nursing Work, 2, 13-15 [in Russian].

6. Tykholaz, S.I. (2011). Pedahohichni umovy rozvytku profesiinoi spriamovanosti studentiv vyshchykh medychnykh navchalnykh zakladiv [Pedagogical conditions for the development of the professional orientation of students of higher medical schools]. Candidate's Extended abstract. Vinnytsia [in Ukrainian].

7. Khabusieva, M.S. (2013). Stanovlennia motyvatsiinoi sfery maibutnikh medychnykh pratsivnykiv: psykholohopedahohichni peredumovy [Formation of the motivational sphere of future medical workers: psychological and pedagogical premises]. Visnyk Natsionalnoi akademii Derzhavnoi prykordonnoi sluzhby Ukrainy - Bulletin of the National Academy of the State Border Guard Service of Ukraine, 3. - Retrieved from: http://nbuv.gov.ua/UJRN/ Vnadps_2013_3_39. [in Ukrainian]. 